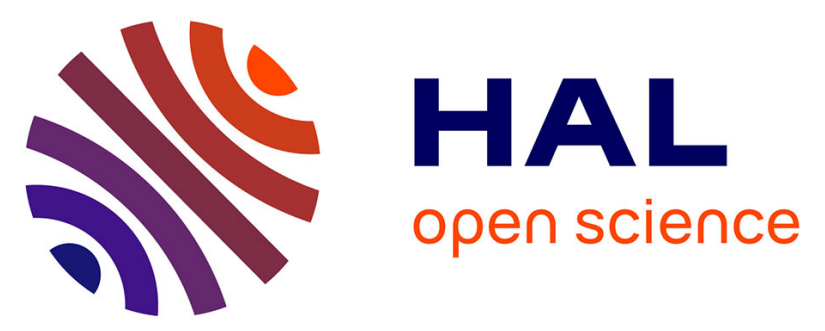

\title{
Distributions and seasonal variations of tropospheric ethene (C2H4) from Atmospheric Chemistry Experiment (ACE-FTS) solar occultation spectra
}

H. Herbin, Daniel Hurtmans, Lieven Clarisse, Solène Turquety, Cathy

Clerbaux, C.P. Rinsland, C. Boone, P.F. Bernath, Pierre-François Coheur

\section{To cite this version:}

H. Herbin, Daniel Hurtmans, Lieven Clarisse, Solène Turquety, Cathy Clerbaux, et al.. Distributions and seasonal variations of tropospheric ethene $(\mathrm{C} 2 \mathrm{H} 4)$ from Atmospheric Chemistry Experiment (ACE-FTS) solar occultation spectra. Geophysical Research Letters, 2009, 36 (4), pp.L04801. 10.1029/2008GL036338. hal-00362483

\section{HAL Id: hal-00362483 https://hal.science/hal-00362483}

Submitted on 1 Feb 2016

HAL is a multi-disciplinary open access archive for the deposit and dissemination of scientific research documents, whether they are published or not. The documents may come from teaching and research institutions in France or abroad, or from public or private research centers.
L'archive ouverte pluridisciplinaire HAL, est destinée au dépôt et à la diffusion de documents scientifiques de niveau recherche, publiés ou non, émanant des établissements d'enseignement et de recherche français ou étrangers, des laboratoires publics ou privés. 


\title{
Distributions and seasonal variations of tropospheric ethene $\left(\mathrm{C}_{2} \mathrm{H}_{4}\right)$ from Atmospheric Chemistry Experiment (ACE-FTS) solar occultation spectra
}

\author{
H. Herbin, ${ }^{1,2}$ D. Hurtmans, ${ }^{1}$ L. Clarisse, ${ }^{1}$ S. Turquety,${ }^{3,4}$ C. Clerbaux, ${ }^{1,3}$ C. P. Rinsland, ${ }^{5}$ \\ C. Boone, ${ }^{6}$ P. F. Bernath, ${ }^{6,7}$ and P.-F. Coheur ${ }^{1}$ \\ Received 14 October 2008; accepted 8 January 2009; published 17 February 2009.
}

[1] This work reports the first measurements of ethene $\left(\mathrm{C}_{2} \mathrm{H}_{4}\right)$ distributions in the upper troposphere. These are obtained by retrieving vertical profiles from 5 to $20 \mathrm{~km}$ from infrared solar occultation spectra recorded in 2005 and 2006 by the Atmospheric Chemistry Experiment-Fourier Transform Spectrometer (ACE-FTS). Background volume mixing ratios (vmrs) ranging from a few to about 50 pptv $\left(10^{-12}\right)$ are measured at the different altitudes, while for certain occultations, vmrs as high as 200 pptv are observed. Zonal distributions and vertically resolved latitudinal distributions are derived for the two year period analyzed, highlighting spatial -including a North-South gradient- as well as seasonal variations. We show the latter to be more pronounced at the highest latitudes, presumably as a result of less active photochemistry during winter. The observation of $\mathrm{C}_{2} \mathrm{H}_{4}$ enhancements in remote Arctic regions at high latitudes is consistent with the occurrence of fast transport processes of gaseous pollution from the continents leading to Arctic haze. Citation: Herbin, H., D. Hurtmans, L. Clarisse, S. Turquety, C. Clerbaux, C. P. Rinsland, C. Boone, P. F. Bernath, and P.-F. Coheur (2009), Distributions and seasonal variations of tropospheric ethene $\left(\mathrm{C}_{2} \mathrm{H}_{4}\right)$ from Atmospheric Chemistry Experiment (ACE-FTS) solar occultation spectra, Geophys. Res. Lett., 36, L04801, doi:10.1029/2008GL036338.

\section{Introduction}

[2] Ethene $\left(\mathrm{C}_{2} \mathrm{H}_{4}\right)$ is one of the most abundant unsaturated hydrocarbons in the atmosphere. Its emissions are estimated to be around $20 \mathrm{Tg} /$ year [Folberth et al., 2006; Horowitz et al., 2003], of which about half originate from biomass burning. Other sources include industrial and biogenic emissions in comparable amounts and smaller oceanic emissions [Folberth et al., 2006; Horowitz et al.,

\footnotetext{
${ }^{1}$ Service de Chimie Quantique et de Photophysique, Université Libre de Bruxelles, Brussels, Belgium.

${ }^{2}$ Now at Laboratoire d'Optique Atmosphérique, Université des Sciences et Technologies de Lille, CNRS, Villeneuve d'Ascq, France.

${ }^{3}$ Service d'Aéronomie, UMR7620, IPSL, CNRS, UPMC Paris 06, Paris, France.

${ }^{4}$ Now at Laboratoire de Météorologie Dynamique, IPSL, CNRS, UPMC Paris 06, Palaiseau, France.

${ }^{5}$ Atmospheric Sciences Competency, NASA Langley Research Center, Hampton, Virgina, USA.

${ }^{6}$ Chemistry Department, University of Waterloo, Waterloo, Ontario, Canada.

${ }^{7}$ Department of Chemistry, University of York, Heslington, UK.
}

Copyright 2009 by the American Geophysical Union. 0094-8276/09/2008GL036338
2003; Sawada and Totsuka, 1986]. The dominant mechanism for the removal of $\mathrm{C}_{2} \mathrm{H}_{4}$ from the atmosphere is the fast reaction with the hydroxyl radical $\mathrm{OH}$ [Atkinson et al., 1997]. Secondary sinks include reaction with ozone and transport to the stratosphere [Sawada and Totsuka, 1986]. Because of this rapid reactivity with $\mathrm{OH}$, ethene has a mean tropospheric lifetime that varies significantly with time and latitude: it ranges from a few hours during summer to about four days in winter [Rudolph et al., 1989; Solberg et al., 1996].

[3] Ethene has been measured in the atmosphere by a variety of techniques, principally at the surface [e.g., Hakola et al., 2006; Sahu and Lal, 2006; Solberg et al., 1996] or during airborne campaigns [e.g., Blake et al., 2003; Karl et al., 2007]. Reported concentrations range from a few pptv to several ppbv $\left(10^{-9}\right)$ in the boundary layer nearby important sources, such as urban areas [Baker et al., 2008] or vegetation fires [e.g., Blake et al., 1996; Hobbs et al., 2003]. As for most alkenes, models generally fail to reproduce the ethene measurements and seasonal variations [e.g., Poisson et al., 2000; Pozzer et al., 2007].

[4] Recently, we have presented satellite observations of ethene for the first time [Coheur et al., 2007], using infrared measurements provided by the ACE-FTS. Although the retrieval of ethene using optical instruments is challenging due to the weak spectral signature, this result triggered analyses on an extended scale. This work presents for the first time distributions of ethene in the upper troposphere, retrieved from ACE-FTS occultations in 2005 and 2006.

\section{Measurements}

[5] The ACE-FTS measures the solar radiation between 750 and $4400 \mathrm{~cm}^{-1}$ at a spectral resolution of $0.02 \mathrm{~cm}^{-1}$ [Bernath et al., 2005]. Launched in August 2003 onboard SCISAT into a $74^{\circ}$ inclined orbit at $650 \mathrm{~km}$ altitude, ACEFTS operates primarily in solar occultation mode. It records up to 15 sunrises and 15 sunsets per day, with an orbital coverage optimized for high latitudes. Level 1 data are transmittance spectra obtained by dividing the atmospheric spectra at given tangent altitudes between 5 and $150 \mathrm{~km}$ by a composite exoatmospheric spectrum from the same occultation.

[6] Operational retrievals provide vertical profiles of temperature, pressure and molecular vmrs for more than a dozen species [Boone et al., 2005]. The high signal-to-noise ratio of the spectra enables extension of the level 2 trace species to weak organic absorbers in some cases, particularly for plumes from biomass fires [Coheur et al., 2007; 


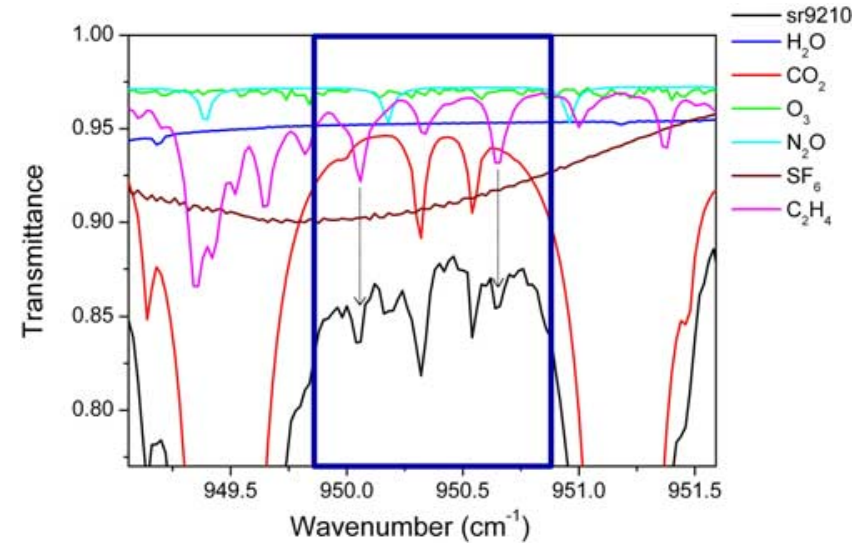

Figure 1. Example of ethene spectral signatures in an ACE-FTS spectrum around $9 \mathrm{~km}$ tangent altitude, measured at $26.96^{\circ} \mathrm{N}, 101.79^{\circ} \mathrm{E}$ on April 28,2005 . The black line represents the measured spectrum and the coloured lines the molecule-by-molecule simulations in the spectral window. The dark blue rectangle identifies the spectral microwindow used for the retrievals and the dotted arrows the position of the dominant ethene lines in it.

Dufour et al., 2006, 2007; Rinsland et al., 2006, 2007a, 2007b].

[7] For this work, we rely on the same retrieval method as described by Coheur et al. [2007]. The spectral window 949.86-950.88 $\mathrm{cm}^{-1}$, which includes the $\mathrm{C}_{2} \mathrm{H}_{4} \nu_{7}$ vibrational band, was chosen in order to handle a larger set of data. Unapodized spectra are analyzed, with an appropriate instrument line shape function [Boone et al., 2005]. The line parameters are from HITRAN 2004 including all recent updates [Rothman et al., 2005]. In the retrieval process, the temperature and pressure profiles are fixed to their values from the ACE-FTS operational processing (version 2.2). The trace gas profiles are similarly taken from version 2.2., but are readjusted, along with those for ethene, for all interferers in the microwindow. The retrievals are performed considering all spectra between 5 and $20 \mathrm{~km}$ tangent height.

\section{Discussion}

[8] Ethene vertical profiles have been successfully retrieved for about half of the ACE-FTS occultations in the two years period considered. This means that for at least the other half the signal was too weak to be detected and the retrieval failed. Overall, this translates to a total of 4292 measurements around $14 \mathrm{~km}$ and 2176 around $6 \mathrm{~km}$, where observations are frequently affected by clouds.

[9] The $\mathrm{C}_{2} \mathrm{H}_{4}$ contribution to the spectra is illustrated in Figure 1 for a measurement at Northern tropical latitude, representative of a relatively elevated vmr (92 pptv) around $9 \mathrm{~km}$. We find that a value of $20 \mathrm{pptv}$ is close to the detection threshold at all altitudes in the troposphere, similar to that of other remote-sensing techniques and significantly higher than that of in-situ air sampling measurements, which can detect vmrs as low as 3 pptv [Blake et al., 2003]. The lowest values retrieved in this work for $\mathrm{C}_{2} \mathrm{H}_{4}$ are not very reliable (error of $100 \%$ or larger) while for higher concentrations, the detection is unambiguous (see Figure 1) and the estimated errors on the retrieved profile do not exceed $40 \%$.

[10] In order to display the ethene distributions and considering the restricted geographical coverage provided by the ACE-FTS, we have accumulated the retrieved vmrs for the two years (Figure 2). The zonal distribution around $6 \mathrm{~km}$ is shown in Figure 2 (top), with vmrs interpolated on a $5^{\circ}$ latitude by $10^{\circ}$ longitude grid. The majority of vmrs are well below 100 pptv, except for some localized grid boxes, which show enhancements above 140 pptv. The air masses with elevated $\mathrm{C}_{2} \mathrm{H}_{4}$ concentrations are likely due to the outflow of continental pollution plumes by rapid lofting processes, whereas lower concentrations result from the horizontal and vertical mixing of sources on timescales not exceeding the ethene lifetime. Overall, we note that the lower values retrieved from the ACE-FTS spectra are within the range of those generally reported from aircraft measurements in the free troposphere [Pozzer et al., 2007, and references therein; Blake et al., 2003]. The observation of enhanced ethene in the upper troposphere is also consistent with earlier observations of urban pollution [Blake et al., 2003] or biomass burning plumes [Pickering et al., 1996]. Figure 2 (bottom) shows the average latitudinal trend of the ethene profiles for three altitudes (around 6, 8 and

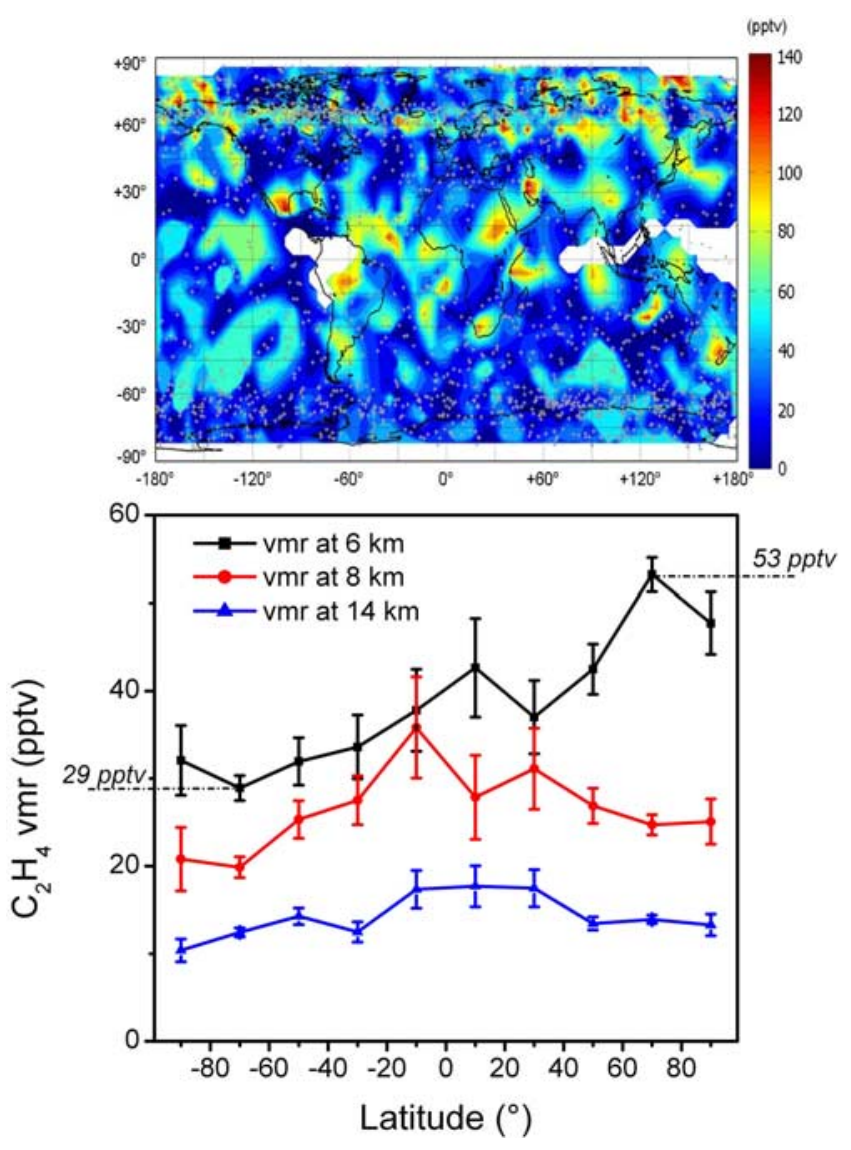

Figure 2. (top) Zonal distribution of $\mathrm{C}_{2} \mathrm{H}_{4}$ around $6 \mathrm{~km}$ in the troposphere, for the entire 2005 and 2006 dataset. (bottom) Latitudinal trends of the $\mathrm{C}_{2} \mathrm{H}_{4}$ vmrs (pptv) around 6,8 and $14 \mathrm{~km}$ obtained by averaging the retrieved values in 20 latitude bins. The error bar is one standard deviation divided by the square-root of the number of observations. 


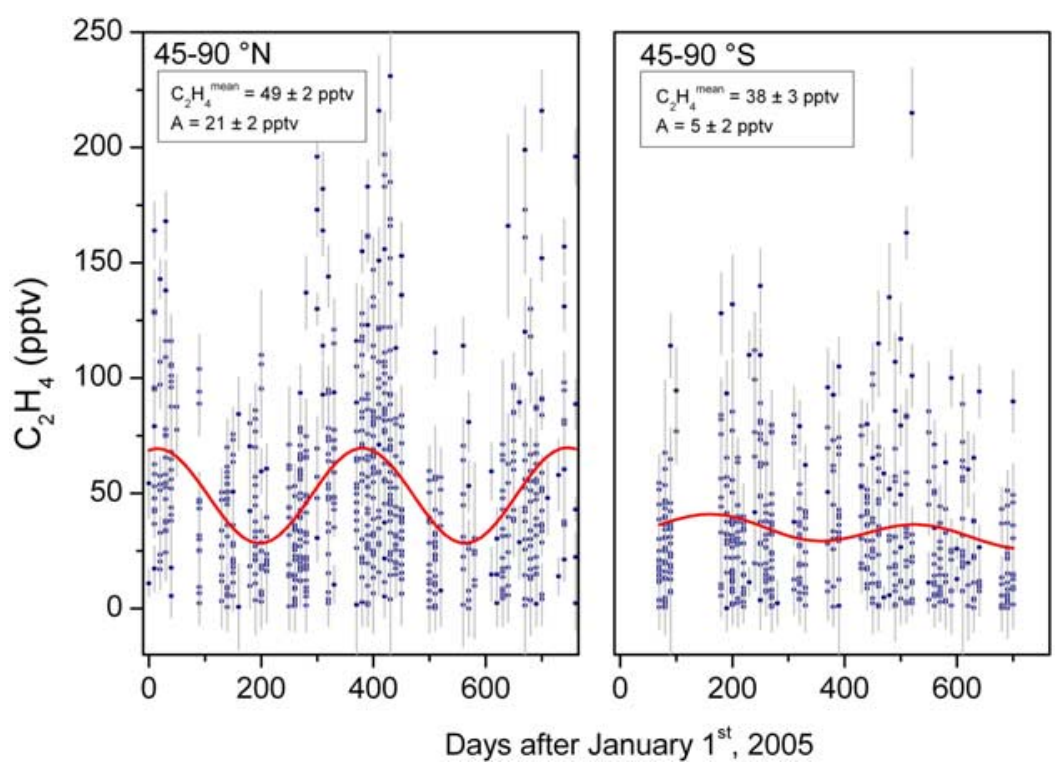

Figure 3. Time series of the $\mathrm{C}_{2} \mathrm{H}_{4}$ mixing ratio (pptv) around $6 \mathrm{~km}$, for the (left) $45-90^{\circ} \mathrm{N}$ and (right) $45-90^{\circ} \mathrm{S}$ latitude bands. The grey lines represent the statistical error from the retrieval. The red curves are sine functions adjusted to go through the measured data, with mean values, amplitude (A) and annual offset as fitted parameters.

$14 \mathrm{~km}$ ), considering the entire 2005-2006 dataset, thus minimizing but not fully removing the effects of seasonal variations, as discussed below. For Figure 2 (bottom), the measurements were averaged in $20^{\circ}$ latitude bins, with the one standard deviation of the ensemble of values divided by the square-root of the number of observations being provided as an estimate of the variability. Around $6 \mathrm{~km}$, we observe a latitudinal gradient, with an average vmr in the Arctic about 50\% higher than in the Antarctic. The concentrations progressively decrease with increasing altitude, following the tropopause height, and larger concentrations are found in the tropical upper troposphere.
[11] Ethene time series are shown in Figure 3, again around $6 \mathrm{~km}$, for the $45-90^{\circ}$ latitude bands in both hemispheres. The shapes of the seasonal cycles, shown by the curves in Figure 3, are modelled with a sine function with the mean value and amplitude as principal fitted parameters. The derived mean vmrs over the two years are $49 \pm 2$ and $38 \pm 3$, for the $45-90^{\circ} \mathrm{N}$, and $45-90^{\circ} \mathrm{S}$ latitude bands, respectively, thus confirming the North/South gradient already apparent in Figure 2 at the same altitude. It should be stressed that these average vmrs remain likely biased towards high values due to the difficulty in measuring low concentrations with the ACE-FTS. As apparent from Figure 3, the amplitude of the seasonal cycle in the southern hemi-
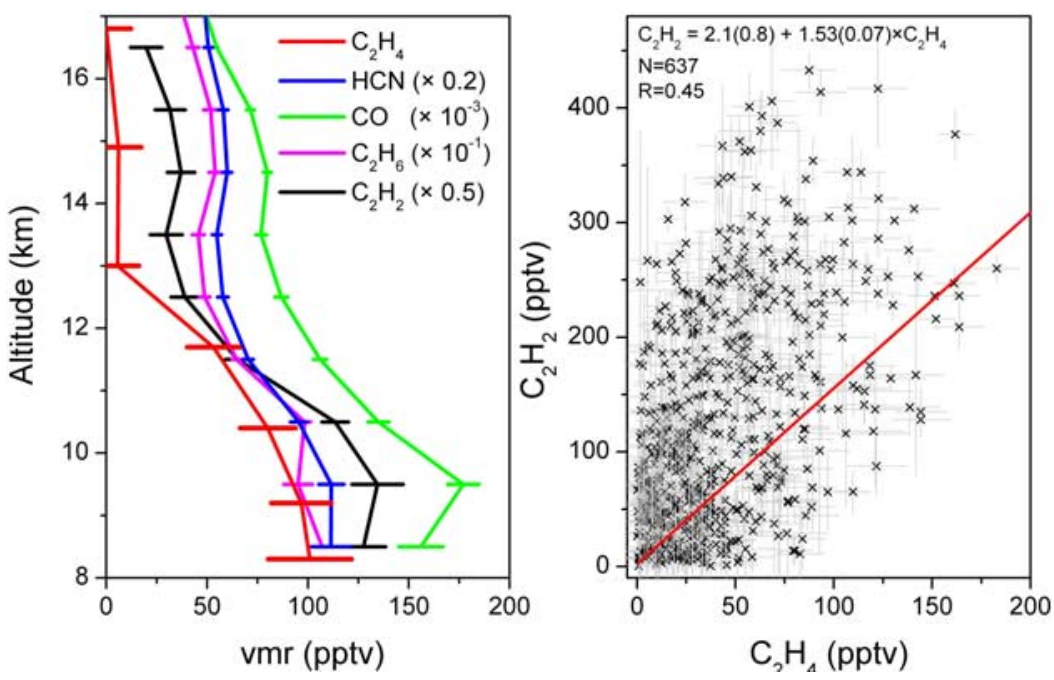

Figure 4. (left) Example of retrieved $\mathrm{C}_{2} \mathrm{H}_{4}$ profiles from the same occultation as in Figure 1 and comparison with other carbon tracers. (right) Relationship between the $\mathrm{C}_{2} \mathrm{H}_{4}$ and $\mathrm{C}_{2} \mathrm{H}_{2}$ vmrs around $6 \mathrm{~km}$ in the troposphere, considering all measured data points. The red curve is obtained by fitting a line through the data points, weighted by their respective uncertainties. The equation of the linear regression, the number of points $(\mathrm{N})$ and the corresponding correlation coefficient $\mathrm{R}$ are given in the upper left corner. 
sphere is weak ( $5 \pm 2$ pptv for the $45-90^{\circ} \mathrm{S}$ band) and questionable in light of the high variability of the individual measurements. It is larger in the northern hemisphere $(21 \pm$ 2 pptv for the $45-90^{\circ} \mathrm{N}$ band) and especially at higher latitudes, although clearly existing at mid-latitudes also (a value of $14 \pm 3 \mathrm{pptv}$ is calculated for the $30-60^{\circ} \mathrm{N}$ band excluding the Arctic). For the two bands shown in Figure 3, low mixing ratio values prevail during the summer months and elevated mixing ratios in winter, with minima and maxima found around the summer and winter solstices, respectively. No seasonal variations are observed in the tropics. To our knowledge, these spatial and temporal variations in the upper troposphere have never been reported before and show general qualitative consistency with ground measurements [Hakola et al., 2006, and references therein; Sahu and Lal, 2006].

[12] From the spatial and seasonal variations displayed in Figures 2 and 3 we conclude that larger $\mathrm{C}_{2} \mathrm{H}_{4}$ mixing ratios are found in northern high latitudes during winter, with maxima close to those of the highly polluted local plumes found at tropical and mid-latitudes. The average winter maximum vmr for the $60-90^{\circ} \mathrm{N}$ band (not shown) is indeed well above 50 pptv, with several values reaching 200 pptv. The observation of such enhancements for the short-lived $\mathrm{C}_{2} \mathrm{H}_{4}$ molecule in the remote Arctic region likely originates from the uplift of continental pollution, from North America, Asia and Europe, followed by poleward transport [Stohl, 2006]. Subsequent descent of these air masses down to the lower troposphere is considered to be one of the main transport pathways which results in a high-level of pollutants within the Arctic haze that regularly occurs in winter and early spring [Law and Stohl, 2007, and references therein]. From this point of view, it is interesting to note that most ACE profiles with elevated $\mathrm{C}_{2} \mathrm{H}_{4}$ concentrations at these high northern latitudes are correlated with enhancements of other pollutants, including carbon monoxide (CO), ethane $\left(\mathrm{C}_{2} \mathrm{H}_{6}\right)$ and ethyne $\left(\mathrm{C}_{2} \mathrm{H}_{2}\right)$ and occasionally $\mathrm{HCN}$ (Figure 4), suggesting in this case a biomass burning origin [Rinsland et al., 2007a]. However, we find a moderate correlation between $\mathrm{C}_{2} \mathrm{H}_{4}$ and these tracers on a global scale at $6 \mathrm{~km}$ in the troposphere, as illustrated in Figure 4 (right) by the correlation with $\mathrm{C}_{2} \mathrm{H}_{2}$.

\section{Conclusions}

[13] Distributions of $\mathrm{C}_{2} \mathrm{H}_{4}$ in the upper troposphere (5 to $20 \mathrm{~km}$ altitude range) have been obtained from the ACEFTS infrared satellite measurements in 2005 and 2006. Despite poor geographical coverage, especially in the tropics, zonal and latitudinal distributions have been gathered and analyzed. We have found that the $\mathrm{C}_{2} \mathrm{H}_{4}$ mixing ratios in the troposphere are characterized by a north to south gradient, with seasonally average values larger by $10 \mathrm{pptv}$ at northern as compared to southern mid and high latitudes ( $49 \pm 1$ and $38 \pm 3$ pptv). The amplitude of the seasonal cycle was found to be largest in the northern hemisphere, with derived seasonal peak values up to $70 \mathrm{pptv}$ and individual concentrations up to $200 \mathrm{pptv}$ at polar latitudes around the winter solstice. These enhancements in the remote Arctic upper troposphere likely originate from transported continental pollution plumes, as also revealed by a good correlation with $\mathrm{CO}, \mathrm{C}_{2} \mathrm{H}_{2}$ and $\mathrm{C}_{2} \mathrm{H}_{6}$ in individual profiles. More generally, we anticipate that these measured distributions of ethene will help in the modelling of chemical processes occurring in the upper troposphere, in particular over remote Arctic regions. The simultaneous high precision of ACE-FTS measurements of species with a range of atmospheric lifetimes offer the potential to use such chemical transport model predictions to quantify the location of the source region, the type of emission (relative contributions of biomass burning, biogenic, oceanic, and industrial sources), the age of the air in the observed parcel and their contributions to ozone production and air quality.

[14] Acknowledgments. The research in Belgium was funded by the Fonds de la Recherche Scientifique (FRS-FNRS, M.I.S. $n^{\circ}$ F.4511.08), the Belgian State Federal Office for Scientific, Technical and Cultural Affairs and the European Space Agency (ESA-Prodex arrangement C90-327). Financial support by the "Actions de Recherche Concertées" (Communauté Française de Belgique) is also acknowledged. C. Clerbaux and S. Turquety are grateful to CNES (Centre National d'Etudes Spatiales) for financial support. The ACE mission is supported primarily by the Canadian Space Agency (CSA) and some support was also provided by the UK Natural Environment Research Council (NERC). NASA Langley Research Center was supported by NASA's Atmospheric Chemistry and Modeling Program (ACMAP). P.F. Coheur and L. Clarisse are Research Associate and Scientific Collaborator with the F.N.R.S (Belgium).

\section{References}

Atkinson, R., D. L. Baulch, R. A. Cox, R. F. Hampson Jr., J. A. Kerr, M. J. Rossi, and J. Troe (1997), Evaluated kinetic and photochemical data for atmospheric chemistry. Organic species: Supplement VII, J. Phys. Chem. Ref. Data, 28, 191-393.

Baker, A. K., A. J. Beyersdorf, L. A. Doezema, A. Katzenstein, S. Meinardi, I. J. Simpson, D. R. Blake, and F. S. Rowland (2008), Measurements of nonmethane hydrocarbons in 28 United States cities, Atmos. Environ., 42, 170-182.

Bernath, P. F., et al. (2005), Atmospheric Chemistry Experiment (ACE): Mission overview, Geophys. Res. Lett., 32, L15S01, doi:10.1029/ 2005GL022386.

Blake, N. J., D. R. Blake, B. C. Sive, T.-Y. Chen, F. S. Rowland, J. E. CollinsJr, G. W. Sachse, and B. E. Anderson (1996), Biomass burning emissions and vertical distribution of atmospheric methyl halides and other reduced carbon gases in the South Atlantic region, J. Geophys. Res., 101, 24,151-24,164.

Blake, N. J., et al. (2003), NMHCs and halocarbons in Asian continental outflow during the Transport and Chemical Evolution over the Pacific (TRACE-P) field campaign: Comparison with PEM-West B, J. Geophys. Res., 108(D20), 8806, doi:10.1029/2002JD003367.

Boone, C. D., R. Nassar, K. A. Walker, Y. Rochon, S. D. McLeod, C. P. Rinsland, and P. F. Bernath (2005), Retrievals for the atmospheric chemistry experiment Fourier-transform spectrometer, Appl. Opt., 44, 72187231.

Coheur, P.-F., et al. (2007), ACE-FTS observation of a young biomass burning plume: First reported measurements of $\mathrm{C}_{2} \mathrm{H}_{4}, \mathrm{C}_{3} \mathrm{H}_{6} \mathrm{O}, \mathrm{H}_{2} \mathrm{CO}$ and PAN by infrared occultation from space, Atmos. Chem. Phys., 7, $5437-5446$

Dufour, G., C. D. Boone, C. P. Rinsland, and P. F. Bernath (2006), First space-borne measurements of methanol inside aged southern tropical to mid-latitude biomass burning plumes using the ACE-FTS instrument, Atmos. Chem. Phys., 6, 3463-3470.

Dufour, G., S. Szopa, D. A. Hauglustaine, C. D. Boone, C. P. Rinsland, and P. F. Bernath (2007), The influence of biogenic emissions of upper-tropospheric methanol as revealed from space, Atmos. Chem. Phys., 7, 61196129.

Folberth, G. A., D. A. Hauglustaine, J. Lathière, and F. Brocheton (2006), Interactive chemistry in the Laboratoire de Météorologie Dynamique general circulation model: Model description and impact analysis of biogenic hydrocarbons on tropospheric chemistry, Atmos. Chem. Phys., 6, $2273-2319$

Hakola, H., H. Hellen, and T. Laurila (2006), Ten years of light hydrocarbons $\left(\mathrm{C}_{2}-\mathrm{C}_{6}\right)$ concentration measurements in background air in Finland, Atmos. Environ., 40, 3621-3630.

Hobbs, P. V., P. Sinha, R. J. Yokelson, T. J. Christian, D. R. Blake, S. Gao, T. W. Kirchstetter, T. Novakov, and P. Pilewskie (2003), Evolution of gases and particles from a savanna fire in South Africa, J. Geophys. Res., 108(D13), 8485, doi:10.1029/2002JD002352. 
Horowitz, L. W., et al. (2003), A global simulation of tropospheric ozone and related tracers: Description and evaluation of MOZART, version 2, J. Geophys. Res., 108(D24), 4784, doi:10.1029/2002JD002853.

Karl, T. G., T. J. Christian, R. J. Yokelson, P. Artaxo, W. M. Hao, and A. Guenther (2007), The tropical forest and fire emissions experiment: Method evaluation of volatile organic compound emissions measured by PTR-MS, FTIR and GC from tropical biomass burning, Atmos. Chem. Phys., 7, 5883-5897.

Law, K. S., and A. Stohl (2007), Arctic air pollution: Origins and impacts, Science, $315,1537-1540$.

Pickering, K. E., et al. (1996), Convective transport of biomass burning emissions over Brazil during TRACE A, J. Geophys. Res., 101, 23,99324,012 .

Poisson, N., M. Kanakidou, and P. J. Crutzen (2000), Impact of nonmethane hydrocarbons on tropospheric chemistry and the oxidizing power of the global troposphere: 3-dimensional modeling results, J. Atmos. Chem., 36, 157-230.

Pozzer, A., P. Jöckel, H. Trost, R. Sander, L. Ganzeveld, A. Kerkweg, and J. Lelieveld (2007), Simulating organic species with the global atmospheric chemistry general circulation model ECHAM5/MESSy1: A comparison of model results with observations, Atmos. Chem. Phys., 7, $2527-$ 2550 .

Rinsland, C. P., et al. (2006), First space-based observations of formic acid (HCOOH): Atmospheric Chemistry Experiment austral spring 2004 and 2005 Southern Hemisphere tropical-mid-latitude upper tropospheric measurements, Geophys. Res. Lett., 33, L23804, doi:10.1029/2006GL027128. Rinsland, C. P., G. Dufour, C. D. Boone, P. F. Bernath, L. Chiou, P.-F. Coheur, S. Turquety, and C. Clerbaux (2007a), Satellite boreal measurements over Alaska and Canada during June-July 2004: Simultaneous measurements of upper tropospheric $\mathrm{CO}, \mathrm{C}_{2} \mathrm{H}_{6}, \mathrm{HCN}, \mathrm{CH}_{3} \mathrm{Cl}, \mathrm{CH}_{4}$, $\mathrm{C}_{2} \mathrm{H}_{2}, \mathrm{CH}_{3} \mathrm{OH}, \mathrm{HCOOH}, \mathrm{OCS}$, and $\mathrm{SF}_{6}$ mixing ratios, Global Biogeochem. Cycles, 21, GB3008, doi:10.1029/2006GB002795.

Rinsland, C. P., P.-F. Coheur, H. Herbin, C. Clerbaux, C. D. Boone, P. F. Bernath, and L. Chiou (2007b), Detection of elevated tropospheric $\mathrm{H}_{2} \mathrm{O}_{2}$ (hydrogen peroxide) mixing ratios in ACE (atmospheric chemistry ex- periment) subtropical infrared solar occultation spectra, J. Quant. Spectrosc. Radiat. Transfer, 107, 340-348.

Rothman, L. S., et al. (2005), The HITRAN 2004 molecular spectroscopic database, J. Quant. Spectrosc. Radiat. Transfer, 96, 139-204.

Rudolph, J., A. Khedim, and D. Wagenbach (1989), The seasonal variation of light nonmethane hydrocarbons in the Antarctic troposphere, J. Geophys. Res., 94, 13,039-13,044.

Sahu, L. K., and S. Lal (2006), Characterization of $\mathrm{C}_{2}-\mathrm{C}_{4} \mathrm{NMHCs}$ distributions at a high altitude tropical site in India, J. Atmos. Chem., 54, 161175 .

Sawada, S., and T. Totsuka (1986), Natural and anthropogenic sources and fate of atmospheric ethene, Atmos. Environ., 20, 821-832.

Solberg, S., C. Dye, N. Schmidbauer, A. Herzog, and R. Gehrig (1996) Carbonyls and nonmethane hydrocarbons at rural European sites from Mediterranean to the Arctic, J. Atmos. Chem., 25, 33-66.

Stohl, A. (2006), Characteristics of atmospheric transport into the Arctic troposphere, J. Geophys. Res., 111, D11306, doi:10.1029/2005JD006888.

P. F. Bernath and C. Boone, Chemistry Department, University of Waterloo, 200 University Avenue West, Waterloo, ON N2L 3G1, Canada. L. Clarisse, P.-F. Coheur, and D. Hurtmans, Service de Chimie Quantique et de Photophysique, Université Libre de Bruxelles, 50 avenue F. D. Roosevelt, B-1050 Brussels, Belgium. (pfcoheur@ulb.ac.be)

H. Herbin, Laboratoire d'Optique Atmosphérique, Université des Sciences et Technologies de Lille, CNRS, F-59655 Villeneuve d'Ascq CEDEX, France.

C. Clerbaux, Service d'Aéronomie, UMR7620, IPSL, CNRS, UPMC Paris 06, Paris, France.

C. P. Rinsland, Atmospheric Sciences Competency, NASA Langley Research Center, Mail Stop 401A, 21 Langley Boulevard, Hampton, VA 23681, USA.

S. Turquety, Laboratoire de Météorologie Dynamique, IPSL, CNRS, UPMC Paris 06, F-91128 Palaiseau CEDEX, France. 